\title{
ISSUE TOUCHING SCHOOL QUALITY IN AMHARA REGION
}

\author{
Berhanu Asaye Agajie ${ }^{1}$ \\ ${ }^{1}$ Injibara College of Teachers Education, Injibara, Ethiopia. E-mail: berhanuas@gmail.com
}

\begin{abstract}
The objective of this study was to explore factors that affect quality education in the Amhara region. A descriptive survey method, purposive and stratified random sampling techniques were used to examine research objective. Tools used in collecting data were questionnaire and focused group discussion. The finding showed that positive early experiences and interactions, disciplined school systems, providing an adequate number of teachers, access to toilets, availability of relatively suitable class sizes, welcoming schools boarding atmospheres, learner centered teaching practices, professional mobility and growth were strengths of schools in the region. However, violation conditions, professional inflexibility, incompatible teachers working conditions, irregularity of students' class attending, lack of life skill curriculums, schools facilities, shortage of instructional materials, clean water supply and not have ongoing trainings have negative impact on quality education. As a result, it is recommended that a further research on quality education, focusing specifically indicators that support a quality primary education.

Key words: Amhara region. Elementary school. Quality Education. Quality indicator.
\end{abstract}

\section{FATORES QUE AFETAM A QUALIDADE DA EDUCAÇÃO NA REGIÃO DE AMHARA}

\section{RESUMO}

Este estudo teve como objetivo analisar os fatores que afetam a educação de qualidade na região de Amhara, Ethiopia. Na pesquisa descritiva, técnicas de amostragem aleatória estratificada e proposital foram utilizadas para examinar o objetivo da investigação. As ferramentas adotadas na coleta de dados foram o questionário e o grupo focal. Os dados evidenciaram que experiências iniciais e interações positivas, sistemas escolares disciplinados, a garantia de um número adequado de professores, o acesso a banheiros, o tamanho das turmas, a criação de ambientes acolhedores, as práticas de ensino centradas nos alunos, a mobilidade profissional foram pontos fortes das escolas na região. No entanto, condições de violação, inflexibilidade profissional, condições de trabalho incompatíveis para os professores, irregularidade na frequência dos alunos, a ausência de habilidades para a vida nos currículos, as instalações escolares, a escassez de materiais instrucionais, o não fornecimento de água potável e de treinamentos contínuos têm impacto negativo na qualidade da educação. A partir dos resultados, recomenda-se uma pesquisa adicional sobre educação de qualidade, focando especificamente nos indicadores que apoiam uma educação primária de qualidade.

Palavras-chave: Região de Amhara. Escola primária. Educação de qualidade. Indicador de qualidade.

\section{FACTORES QUE AFECTAN LA CALIDAD DE LA EDUCACIÓN EN LA REGIÓN DE AMHARA}

\section{RESUMEN}

Este estudio tuvo como objetivo analizar los factores que afectan la educación de calidad en la región de Amhara, Etiopía. En la investigación descriptiva, se utilizaron técnicas de muestreo aleatorio estratificado y con propósito para examinar el propósito de la investigación. Las herramientas adoptadas para la recopilación de datos fueron el cuestionario y el grupo focal. Los datos mostraron que las experiencias iniciales y las interacciones positivas, los sistemas escolares disciplinados, el número adecuado de maestros, acceso a cuartos de baños, tamaños de clases, creación de ambientes acogedores, prácticas de enseñanza centradas en el alumno, movilidad profesional fueron los puntos fuertes de las escuelas de la región. Sin embargo, condiciones de violación, inflexibilidad profesional, condiciones de trabajo 
incompatibles para los docentes, asistencia irregular de los alumnos, falta de habilidades para la vida en los planes de estudio, instalaciones escolares, escasez de materiales de instrucción, falta de suministro de agua potable y la capacitación continua tienen un impacto negativo en la calidad de la educación. Con base en los resultados, se recomienda una investigación adicional sobre educación de calidad, enfocándose específicamente en los indicadores que apoyan la educación primaria de calidad.

Palabras clave: Región de Amhara. Escuela primária. Educación de calidad. Indicador de calidad.

\section{INTRODUCTION}

The 1994 Education and Training Policy have shaped the overall education system, policy and strategy of Ethiopia. However, for a couple of decades, different policies and strategies have been developed and implemented. Among these policies and strategies, the most prominent ones are the successive and progressive education sector development plans (ESDP II, III, IV, and I). This Education Sector Development Program has been devoted to improving the overall education system and school performance in general, and for all children to have access to quality basic education in particular. In addition, certain changes and flexibility within the general policy framework, have allowed regional governments to adapt the education objectives, strategies and programs in a way that supports the national educational and training policy (FEDERAL DEMOCRATIC REPUBLIC GOVERNMENT OF ETHIOPIA, 1994). Another important strategic document of the Government of Ethiopia is the Growth and Transformation Plan (2010) which has provided for the expansion of quality education. During the first year of Growth and Transformation Plan period (2010/11), the findings are encouraging. The sector performance has improved universal access to primary education, and the quality of education (MOE, 2010a, 2010b).

\subsection{STATEMENT OF THE PROBLEM}

The research findings by Ethiopia Early Grade Reading Assessment Data Analytic Report (2010), proposes that there are poor reading and writing skills at three-grade levels in almost all regions of Ethiopia. Although students in grades 1-3 have received instruction in three early grades, reading curricular themes their proficiency level on these themes is unsatisfactory. These themes include reading letters and words and reading and comprehending simple sentences and phrases. In many cases, the distinctions among the three grade levels seem to be blurred. According to the research finding, students' proficiency level in reading and writing was presuming. Moreover, Key educational services Plc (2012) has stated that low quality education exists in Amhara region. Therefore, the rationale of this research design is to analyzing factors affecting quality education in selected primary schools of Amhara region.

\subsection{THE OBJECTIVE OF THE STUDY}

The objective of this study is to explore factors that affect quality education in selected primary schools of Amhara region.

\section{REVIEW OF RELATED LITERATURE 2.1 QUALITY EDUCATION}

Numerous definitions of quality in education exist, contributing to the complexity and comprehensive nature of the concept. The terms competence, effectiveness, equity and quality have often been using synonymously. Significant agreement exists around the fundamental dimensions of quality education today. Systems that hug transform through data generation, use and self-assessment are more probably to offer quality education to students (MAYER; MULLENS; MOOR, 2000).

UNICEF has provided guidance in identifying quality indicators. For example, the organization has emphasized that the Darkar Framework provides guidance in identifying indicators. Its document Defining Quality in Education recognizes five dimensions of quality: learners, environments, content, processes and outcomes, founded on the rights of the whole child, and all children, to survival, protection, development and participation (UNICEF, 2000).

\subsection{QUALITY LEARNERS}

The first indicator is that children need to be physically and psychosocially healthy to be ready to learn. Sufficient diet is important for normal brain development in the early years. In addition, early detection and intervention for children with disabilities can improve chances for healthy development. Prevention of infection, disease and injury prior to school enrolment are 
also critical to the early development of a quality learner (MAXWELL, 2004). Positive early experience and interactions are very important to preparing a quality learner. Children who participate in early involvement programs do better in primary school than those who do not benefit from formal early child programs (UNICEF, 1998). When children are in school age, research indicates that to achieve academically, children must regularly attend school (FULLER et al., 1999).

Parental participation at all grade levels, as another indicator of school quality, it is a critical factor influencing quality of education (HENDERSON, 1994). This includes both teachers' attempts to involve parents in ongoing classroom or school activities and parents' involvement in learning activities at home. However, not all parents have the tools and background to support their children's cognitive and psychosocial growth throughout their school years (CARRON; CHAU, 1996). To ensure the quality of schools and student learning, parents must be involved at all levels in the school. Another essential ingredient for a successful educational system is a quality-learning environment.

\subsection{QUALITY LEARNING ENVIRONMENTS}

A quality-learning environment includes the presence of sufficient instructional materials and textbooks, adequate working conditions for students and teachers, and the ability of teachers to use certain instructional approaches (BENNETT, 2001). School infrastructure factors are on-site accessibility of laboratories and a clean water supply, access to toilet, classroom maintenance, and space and furniture availability. These factors all have an impact on critical learning factors, especially time on task (FULLER, 1999). Even when schools do have adequate infrastructure, sufficient class sizes, the ratio of students to teachers makes it difficult to provide adequate instruction. In addition, policies that support universal access and parent's willing allow their children to attend school have resulted in the need to accommodate large numbers of new students (HECK, 2000). Moreover, the schools need to provide access for children with physical disabilities.

Quality indicators of the classroom environment include classroom rules and policies that are understandable, reasonable, and are agreed upon by the students, teachers, administrators, and parents. Constructive discipline and reinforcement of positive behavior procedures are also quality indicators (CRAIG; PLESSIS, 1998). The school should provide a welcoming and safe environment that supports student learning.

The environment should support equity within ethnic and language minorities, either politically or geographically groups, and groups at low socio- economic levels. In general, continued implementation of these indicators inmost learning environments needs to happen to advance learning opportunities for children of all abilities and backgrounds (CARRON; CHAU, 1996).

\subsection{QUALITY CONTENT}

Quality content refers to the intended and taught curriculum of schools. Nationwide goals for learning, and outcome statements that translate those goals into measurable objectives should provide the starting point for the development and implementation of curriculum (UNICEF, 2000). The specific content of school curriculum is determined by local and national values. Local level interests may also have an impact on and contribute to the quality of educational content. The Curriculum should emphasize (a) deep rather than broad coverage of important areas of knowledge; (b) use authentic and contextualized problems of study, and (c) encourage problem solving that stresses skills development as well as knowledge acquisition. Moreover, curriculum should also provide for individual differences. When planning instruction it is important to closely coordinate and selectively integrate subject matter, and focus on results or standards and targets for student learning (GLATTHORN; JAILALL, 2000). Curriculum structure should also be gender sensitive and inclusive of children with miscellaneous abilities and backgrounds, and responsive to emerging issues such as HIV/AIDS and conflict resolution.

Literacy, the capability to read, write, speak and listen, is one of the main goals of formal education. Literacy skills are frequently taught as a separate subject in a language course, where the instruction tends to be linear; first teaching aural skills, then speaking, reading, and writing skills (MAXWELL, 2004). In contrast, numeracy integrates variety of skills from basic arithmetic and logical reasoning, to advanced mathematics and interpretative communication 
skills. In addition, life skills curriculum focuses on attitudes, values, and behavioral change, rather than seeking to provide student with a body of knowledge on specific skills (DESIMONE, 1999). The life skills curriculum is mean to enable learners to resolve conflict and make decisions.

\subsection{QUALITY PROCESSES}

The school quality is relatively high if teachers have high academic skills, teach in the field they are trained, have at least a number of years of teaching experience, and play a part in professional development programs (MAYER; MULLENS; MOORE, 2000). The experience and qualifications of teachers understood to have a straight impact on the overall performance of both the school and students (SCHEERENS, 1997). In addition, the language schools use for instruction can have positive impact on learning and academic achievement in general.

There should be the highest quality teachers, knowledgeable in developmental stages of learning literacy skills in order, and have deep mastery of both their subject matter and pedagogy to be able to help students' learn (COLBY, 2000). Teaching practices should be learner centered and relevant to students' lives. Thus, ongoing professional development and teacher training that focuses on improving teacher's knowledge is a critical part of building the teacher's capabilities (i.e. appropriate instructional methods). In fact, investing in teacher training is an assured way to have direct impact on the quality of student's education. Teacher training and professional development need not be restricted to off-site teacher training (LATHER, 2004).There is methods that can be used to provide professional development at the school and classroom level.

To be effective, teachers require governments who are supportive of education systems. Managerial support for teaching and learning takes many forms, including such measures as advocating for better conditions and professional development, respecting teachers' autonomy and professionalism and developing inclusive decision-making processes. In addition, teachers should be providing opportunities for professional mobility and growth. Thus, teachers living conditions should be suitable for their life.

\subsection{QUALITY OUTCOMES}

Quality outcomes focuses on what children know and what they can do. As well as their attitudes and expectations, they have for themselves and their societies. Achievement, related to literacy and numeracy, represents key educational outcomes. Other indicators of quality education relate to community participation, and learner's confidence, enhanced life-skills, the capability to make responsible choices and resolve conflict.

The evaluation and assessment of learner outcomes, from the standpoint of quality, is essential to strengthening and improving educational systems. Therefore, the outcomes of elementary schools should assure that students could read, write and calculate. To insure quality education, assessment of academic achievement outcomes has most often been formative assessments (EUROPEAN REPORT, 2000). In contrast, parents tend to see academic achievement as closely related to the opportunity for social promotion and employment. These anticipated outcomes tend to be highly valued by families future employment possibilities that result from education seem to be a primary factor in the demand for primary education (BERGMANN, 1996).

Students should receive services to improve their health and curricular content that increases their knowledge and affects their behavior related to health and hygiene. Schools that strive for quality outcomes by bringing together the many elements of quality educational programs exist around the world (CLASON; DORMODY, 1994).

\section{METHODOLOGY}

The descriptive survey research design was used to assess factors that affect elementary school quality education. The target populations of this research were teachers that teach in elementary schools of Amhara region. Physical education, social science, language, science and mathematics department summer program graduate teachers from Injibara College of teachers' education were involved in the research. Archival and other important documents were also used to enrich the study.

Through a purposive sampling technique North Gondar, South Gondar, Western Gojjam, Awi and East Gojjam elementary schools were selected for the study. In addition, through stratified random sampling technique, 45 elementary schools were identified. The required number of male/female participants, $45.75 \%$ male and $54.25 \%$ female teachers (total 360 
teachers), were selected from these schools by using stratified random sampling procedure. After an extensive literature review, questionnaires addressing the five determinants of education quality (UNICEF, 2000) were developed. Teachers' evaluation towards quality education using a five point Likert scale questionnaire with strongly agree $(S A)$, agree $(A)$, undecided (UD), disagree (DA), and strongly disagree (SDA). Respondents were asked to rank their agreement with each of statements on a five point Likert scale (CLASON; DORMODY, 1994). In order to authenticate the data, four focus group discussions were conducted by way of (9 male, 9 female) selected physical education, social science, language, science and mathematics summer program graduate teachers.

The necessary data were analyzed using numerically, and the results were presented using tables. Information obtained through questionnaire and group discussions were combined with the quantitative data and analyzed together for each research question.

4.

\section{RESULTS}

Table1. Teachers' demographic data

\begin{tabular}{|l|l|l|l|l|l|}
\hline Service in teaching & Percent (\%) & Sex & Percent & Working area & Percent \\
\hline $5-10$ & 15 & Male & 45.75 & Urban & 29.65 \\
\hline $10-15$ & 49 & Female & 54.25 & Rural & 70.35 \\
\hline $15-20$ & 26 & Total & $100 \%$ & Total & $100 \%$ \\
\hline 21 and above & 10 & & & & \\
\hline Total & $100 \%$ & & & & \\
\hline
\end{tabular}

Source: Empirical research

According the above table, fifteen percent teachers were working in teaching for less than 10 year. About, $49 \%$ teachers' service was 10 between 15 years. About $26 \%$ of teachers work experience ranged 15 to 20 years. In addition, $10 \%$ of the teachers' have taught about 21 years or more. Approximately $54.25 \%$ participants were female and the remaining
$45.75 \%$ participants were male. Regarding work place, $29.65 \%$ teachers teach in urban, where as $70.35 \%$ of them work in rural areas of the region.

Table 2. The state of quality learners in elementary school

\begin{tabular}{|l|l|l|l|l|l|l|}
\hline No. & Quality learner statements & SA (\%) & A (\%) & $\begin{array}{l}\text { UD } \\
(\%)\end{array}$ & DA (\%) & $\begin{array}{l}\text { SDA } \\
(\%)\end{array}$ \\
\hline 1 & $\begin{array}{l}\text { Learners are healthy, well encouraged and } \\
\text { ready to participate and learn }\end{array}$ & 18 & 38.4 & 4.72 & 32.77 & 6.11 \\
\hline 2 & $\begin{array}{l}\text { Parents support learning and participate in } \\
\text { school related activities. }\end{array}$ & 8 & 18 & 4 & 58 & 12 \\
\hline 3 & $\begin{array}{l}\text { Positive early experiences and interactions } \\
\text { are vital in the school system }\end{array}$ & 19 & 51 & 10 & 18 & 2 \\
\hline 4 & Students attend classes consistently & 6 & 11.25 & 19.5 & 60.25 & 4 \\
\hline
\end{tabular}

Source: Empirical research.

Concerning statement $1,18 \%$ teachers strongly agreed and $38.4 \%$ agreed that students are healthy and ready to participate. Conversely, $4.72 \%$ were undecided, $32.77 \%$ respondents disagreed and $6.11 \%$ subjects strongly disagreeing with the idea. A majority (56.4\%) indicated that learners were healthy, well encouraged and ready to participate and learn. On the other hand, $38.88 \%$ of subjects disagreed and indicated that learners were not healthy, well nourished; not ready to participate, learn, and 
unable to be supported in learning by their families and communities.

In line with statement 2, $8 \%$ respondents strongly agreed and $18 \%$ of them strongly agreed that parents support students learning and participate in school related activities. However, $58 \%$ of respondents disagreed, $12 \%$ disagreed, and $4 \%$ of them were unable to decide if parents participated. The majority respondents (70\%) stated that the trend of parents supporting learning and participating in school related activities were not good. In their group discussion, they stated that lack of support was due to poverty and cultural practices (i.e. many parents prefer children to work on family farms rather than going to school), and the employment prospects of education are grim.

In the subsequent statement 3 , the majority of participants (19\% strongly agree and $51 \%$ agree) indicated that positive early experiences and interactions were vital in their school system. In contrast, $10 \%$ of respondents were undecided, $18 \%$ disagreed, and $2 \%$ strongly disagreed that those positive early experiences and interactions were not vital in the school system. According to the majority agreements (70\%), a positive early experiences and interactions were vital in the elementary school system. Teachers' in-group discussion stated that early childhood interventions also provide the basis for building the capacity of families and communities that were supportive of children's learning and education.

In line with statement 4, $6 \%$ respondents strongly agreed and $11.25 \%$ agree with the importance of students regularly attending class. Nonetheless, $19.5 \%$ students undecided, $60.25 \%$ disagree and $4 \%$ strongly disagree with the concept. The majority disagreements (60.25\%) point out that students were not attending classes consistently.

Table 3. Teachers experience towards quality learning environment

\begin{tabular}{|l|l|l|l|l|l|l|}
\hline No & Statement of quality learning environment & $\begin{array}{l}\text { SA } \\
(\%)\end{array}$ & A (\%) & $\begin{array}{l}\text { UD } \\
(\%)\end{array}$ & $\begin{array}{l}\text { DA } \\
(\%)\end{array}$ & $\begin{array}{l}\text { SDA } \\
(\%)\end{array}$ \\
\hline 1 & $\begin{array}{l}\text { School is well disciplined and has rules and } \\
\text { regulation. }\end{array}$ & 24.16 & 49.46 & 4.44 & 17.22 & 4.72 \\
\hline 2 & $\begin{array}{l}\text { There are adequate instructional materials, } \\
\text { textbooks, working conditions for students and } \\
\text { teachers in the school. }\end{array}$ & 6.38 & 25.83 & 6.94 & 50.58 & 10.27 \\
\hline 3 & $\begin{array}{l}\text { The school provided adequate number of } \\
\text { teachers to deliver quality education. }\end{array}$ & 23.05 & 54.46 & 3.33 & 15.55 & 3.61 \\
\hline 4 & $\begin{array}{l}\text { There are playground and play material } \\
\text { facilities outside for children to play. }\end{array}$ & 10.55 & 22.5 & 5.83 & 51.38 & 9.76 \\
\hline 5 & There is access to toilets. & 27.22 & 54.16 & 0.33 & 8.6 & 9.72 \\
\hline 6 & Drinking water is available in the school. & 16.38 & 14.16 & 3.05 & 8.61 & 57.8 \\
\hline 7 & $\begin{array}{l}\text { The school provides facilities for children with } \\
\text { physical disabilities. }\end{array}$ & 4.72 & 9.72 & 3.61 & 16.95 & 65 \\
\hline 8 & $\begin{array}{l}\text { The class sizes are suitable for teaching } \\
\text { learning. }\end{array}$ & 23.61 & 52.24 & 3.05 & 16.66 & 4.44 \\
\hline 9 & $\begin{array}{l}\text { The school and boarding atmosphere is } \\
\text { welcoming and assures students to have } \\
\text { warmer and relaxing environment. }\end{array}$ & 13.33 & 52.5 & 3.05 & 25 & 6.12 \\
\hline 10 & Violation conditions do not exist. & 11.17 & 15.83 & 3.48 & 19.74 & 49.78 \\
\hline
\end{tabular}

Source: Empirical research.

Regarding statement 1 , the majority of the respondents ( $49.46 \%$ agreed and $24.16 \%$ strongly agreed) that there were disciplined schools, which have rules and regulation. In contrast, $4.44 \%$ subjects were unable to decide, $17.22 \%$ disagreed and $4.72 \%$ strongly disagreed with the idea. The high number of agreements (73.62 \%) showed that there were disciplined schools in Amhara region.

With reference to statement 2, $6.38 \%$ teachers strongly agreed, $25.83 \%$ agreed that there were adequate instructional materials and 
working conditions in their schools. Approximately $6.94 \%$ of respondents were undecided, $50.58 \%$ disagreed and $10.27 \%$ strongly disagreed with the statement. Therefore, numerous disagreements (60.85\%) emphasized that there was scarcity of instructional materials, textbooks, and poor working conditions for students and teachers in schools. Furthermore, respondents' group discussion included concerns that the lack of availability of textbooks and learning materials and furniture available for learning were negatively influencing children learning.

In response to item 3, about $23.05 \%$ subjects strongly agreed and $54.46 \%$ agreed that the school provided an adequate number of teachers to deliver quality education. On the other hand, $3.33 \%$ were undecided, $15.55 \%$ disagreed and $3.61 \%$ strongly disagreed with the statements. The majority of positive responses (77.51 \%) pointed out that the schools provided an adequate number of teachers to deliver quality education.

According to statement 4, adequate playground materials and facilities, $10.55 \%$ of subjects strongly agreed and $22.5 \%$ agreed that there were playground and play material facilities outside for children to play. Conversely, $9.76 \%$ respondents strongly disagreed and $51.38 \%$ disagreed with the statement. The remaining $5.83 \%$ were unable to decide. A majority of the $(61.14 \%)$ reported that, in their school, there were no playground and play material facilities outside for children to play.

Statement 5, addressed the availability of toilets, $27.22 \%$ of the respondents strongly agreed and $54.16 \%$ of them agreed. On the contrary, $8.6 \%$ teachers disagreed, $9.27 \%$ strongly disagree and $0.33 \%$ did not show any response about accessibility of toilet in the school. Various agreements (81.38 \%) demonstrated that schools have access to toilets for teachers and students.

Regarding statement $6,16.38 \%$ teachers were strongly agreed and $14.16 \%$ agreed that a clean water supply was available. On the other hand, about $3.05 \%$ teachers were undecided, $8.61 \%$ subjects disagreed and $57.8 \%$ strongly disagreed. Hence, the number of teachers who disagreed (66.41 \%) emphasized that there is a lack of a clean water supply. Moreover, in-group discussion, teachers declared that students had to leave school and walk long distances for access to clean drinking water. As a result, students did not always return to class.

The responses to statement 7 , indicate that $4.72 \%$ teachers were strongly agreed and $9.72 \%$ were agreed that there were facilities for students with physical disabilities. However, 3.61 $\%$ of the respondents were undecided. On the other hand, $16.95 \%$ respondents were disagreeing and $65 \%$ were strongly disagreeing that there were no facilities for students with physical disabilities. A majority of the respondents $(81.95 \%)$ believed that the schools did not provide facilities for children with physically disabilities.

In responses on class size, statement 8 , $23.61 \%$ teachers strongly agreed and $52.24 \%$ agreed that the class sizes were suitable for teaching learning. Alternatively, $3.05 \%$ were undecided. However, $16.66 \%$ respondents disagreed whereas $4.44 \%$ subjects strongly disagreed with the statement. Thus, the number of agreements ( $75.85 \%$ ) concluded that the class sizes were suitable for teaching learning.

In relation to item $9,13.33 \%$ teachers strongly agreed and $52.5 \%$ agreed. That schools and boarding atmospheres were welcoming and provided a relaxing environment However, 3.05 $\%$ were undecided, and $25 \%$ respondents disagree, whereas $6.12 \%$ subjects strongly disagreed with the statement. Therefore, the majority of agreements (65.53\%) affirmed that schools and boarding atmospheres were welcoming and provide students' convenient and relaxing environment.

The responses to statement $10,11.17 \%$ teachers strongly agreed and $15.83 \%$ agreed that violation conditions did not exist in their school. However, $3.48 \%$ respondents were undecided, $19.74 \%$ disagreed and $49.78 \%$ respondents strongly disagreed with the statement. Thus, the majority of respondents who disagreed (69.52\%) asserted that different violation conditions were appearing in the school system. 
Table 4. Teachers assessment towards quality content

\begin{tabular}{|l|l|l|l|l|l|l|}
\hline No & Statement of quality content indicators & SA (\%) & A (\%) & UD (\%) & DA (\%) & SDA (\%) \\
\hline 1 & $\begin{array}{l}\text { Literacy or the ability to read, write and } \\
\text { calculating is frequently considering as } \\
\text { primary goals of education. }\end{array}$ & 65 & 31.94 & 0.55 & 1.96 & 0.55 \\
\hline 2 & $\begin{array}{l}\text { The specific content of school curriculum } \\
\text { depends on local and national values. }\end{array}$ & 4.16 & 31.11 & 5.55 & 46.94 & 12.24 \\
\hline 3 & $\begin{array}{l}\text { Student centered, nondiscriminatory, } \\
\text { standards based curriculum structures are } \\
\text { employed. }\end{array}$ & 12.5 & 41.38 & 5.83 & 28.61 & 11.68 \\
\hline 4 & $\begin{array}{l}\text { Materials are comprehensive, gender } \\
\text { sensitive, relevant to schooling. }\end{array}$ & 9.72 & 48.05 & 4.16 & 29.19 & 8.88 \\
\hline 5 & $\begin{array}{l}\text { Life skill curriculum focuses on attitude, } \\
\text { values, and behavioral changes. }\end{array}$ & 10 & 51.96 & 4.16 & 26.11 & 7.77 \\
\hline
\end{tabular}

Source: Empirical research.

Responses to statement 1 indicate that $65 \%$ of the teachers strongly agreed and $31.94 \%$ agreed that literacy or the ability to read, write and calculating, was frequently considering as primary goals of education. Additionally, $0.55 \%$ subjects were undecided, $1.96 \%$ respondents disagreed, whereas $0.55 \%$ subjects strongly disagreed with the statement. Most of the respondents $(96.94 \%)$ indicated that the ability to read, write and calculate were the main goals of education.

In response to item 2, the dependence of the curriculum on local events, $4.16 \%$ teachers strongly agreed and $31.11 \%$ agreed that the specific content of school curriculum depended on local events. However, $5.55 \%$ were undecided, $46.94 \%$ respondents disagreed and $12.24 \%$ subjects strongly disagreed with the statement. As a result, $(59.18 \%)$ of the respondents indicated that the specific content of school curriculum did not depend on local events.

The responses for item 3 indicate that $12.5 \%$ of teachers strongly agreed and 41.38 $\%$ were agreed with this statement. About $5.83 \%$ of respondents were undecided, 28.61 $\%$ respondent's disagreed and $11.68 \%$ strongly disagreed with the availability of student centered, nondiscriminatory, standards based curriculum. The majority
(53.88 \%) agreed that student centered nondiscriminatory, standard based curriculum structures employed in the school, in contrast to the impact of local events.

Item 4, further explores the content of the curriculum. When asked if the curriculum was comprehensive, gender sensitive and relevant to schooling, $9.72 \%$ teachers was agreed and $48.05 \%$ agreed with the concept. However, $4.16 \%$ were undecided, $29.19 \%$ respondents disagreed and $8.88 \%$ subjects were strongly disagreed with the statement. The majority $(57.77 \%)$ argued that materials were comprehensive, gender sensitive and relevant to schooling.

Regarding item 5, 10 \%teachers were agreed and $51.96 \%$ respondents strongly agreed that life skill curriculum focuses on attitude, values, and behavioral changes. However, $4.16 \%$ of them were undecided, $26.11 \%$ disagreed and $7.77 \%$ strongly disagreed with the statement. The majority $(61.96 \%)$ argued that life skill curriculum focuses on attitude, values, and behavioral changes. Conversely, $38.04 \%$ of subjects disagreed that life skill curriculum was not focused on attitude, values, and behavioral changes. 
Table5. Teachers Experience towards Quality Processes

\begin{tabular}{|c|c|c|c|c|c|c|}
\hline No & Statements quality process & $\begin{array}{l}\text { SA } \\
(\%)\end{array}$ & $A(\%)$ & $\begin{array}{l}\text { UD } \\
(\%)\end{array}$ & $\begin{array}{l}\text { DA } \\
(\%)\end{array}$ & $\begin{array}{l}\text { SDA } \\
(\%)\end{array}$ \\
\hline 1 & $\begin{array}{l}\text { The school has highest quality teachers, those } \\
\text { most capable of helping their students learn, } \\
\text { have deep mastery of both their subject matter } \\
\text { and pedagogy. }\end{array}$ & 21.68 & 52.22 & 4.72 & 11.38 & 10 \\
\hline 2 & $\begin{array}{l}\text { Teachers use traditional methods of } \\
\text { instruction. }\end{array}$ & 5.27 & 46.94 & 5.57 & 32.5 & 9.72 \\
\hline 3 & $\begin{array}{l}\text { Ongoing training for teachers was delivered for } \\
\text { their professional development. }\end{array}$ & 5.29 & 9.72 & 2.5 & 25.55 & 56.94 \\
\hline 4 & $\begin{array}{l}\text { Teaching practices were learner centered and } \\
\text { relevant to student's lives. }\end{array}$ & 27.5 & 60.27 & 3.88 & 3.08 & 5.27 \\
\hline 5 & $\begin{array}{l}\text { Teachers are skilled in evaluation individual } \\
\text { students learning and adapt activities according } \\
\text { to student needs. }\end{array}$ & 5.27 & 16.69 & 2.77 & 51.66 & 23.61 \\
\hline 6 & $\begin{array}{l}\text { Teachers acquire administrative support and } \\
\text { leadership. }\end{array}$ & 2.77 & 26.94 & 6.94 & 50.85 & 12.5 \\
\hline 7 & $\begin{array}{l}\text { The language school use for instruction can } \\
\text { have positive impact on learning and academic } \\
\text { achievement in general. }\end{array}$ & 30 & 52.22 & 5.29 & 11.38 & 1.11 \\
\hline 8 & $\begin{array}{l}\text { Teachers of different subjects and classes } \\
\text { interact in constructive ways to enrich the } \\
\text { curriculum. }\end{array}$ & 2.5 & 16.11 & 5.57 & 26.38 & 49.44 \\
\hline 9 & $\begin{array}{l}\text { Teachers being provided opportunities for } \\
\text { professional mobility and growth. }\end{array}$ & 32.77 & 58.88 & 1.11 & 3.05 & 4.19 \\
\hline 10 & $\begin{array}{l}\text { Teachers work is prescribing and what is the } \\
\text { flexibility available to them to perform their } \\
\text { professional duties. }\end{array}$ & 6.38 & 29.47 & 3.05 & 44.72 & 16.38 \\
\hline 11 & $\begin{array}{l}\text { Teachers working conditions are suitable to } \\
\text { their life. }\end{array}$ & 1.66 & 3.33 & 12.5 & 33.33 & 49.18 \\
\hline
\end{tabular}

Source: Empirical research.

Concerning statement 1 , related to teacher quality, $21.68 \%$ teachers strongly agreed and $52.22 \%$ agreed with the statement. About $4.72 \%$ of the teachers were undecided, $11.38 \%$ respondents disagreed, and while10 \% strongly disagreed. The majority of respondents (73.9\%) maintained that the school had highest quality teachers, those most capable of helping their students learn, and who have deep mastery of both their subject matter and pedagogy.

With reference to item 2 , that explored methods of instruction, $5.27 \%$ teachers strongly agreed and $46.94 \%$ respondents agreed with this statement. On the other hand, $5.57 \%$ were undecided, $32.5 \%$ respondents disagreed and 9 . $72 \%$ subjects strongly disagreed with the concept. The majority of responses (52.21\%) indicated that the teachers used traditional methods of instruction.
The findings for statement 3 , the availability of ongoing teacher training, revealed that $5.29 \%$ of the teachers strongly agreed and $9.72 \%$ agreed with the statement. However, 2.5 $\%$ of the respondents were undecided, $25.55 \%$ respondents disagreed and $56.94 \%$ strongly disagreed with the concept. Therefore, respondents' disagreements (82.49\%) indicated that ongoing trainings for teachers were not provided for their professional development.

Concerning item 4, about $27.5 \%$ respondents strongly agreed and $60.27 \%$ agreed that teaching practices were learner centered and relevant to student's lives. Conversely, 3.88 $\%$ of the respondents were undecided, $3.08 \%$ respondents disagreed and $5.27 \%$ of the respondents strongly disagreed with the statement. As a result, the majority $(87.77 \%)$ agreed that teaching practices were learner 
centered and relevant to student's lives.

With reference to statement 5, that teachers were able to adapt activities to match learner needs, about $5.27 \%$ respondents strongly agreed and $16.69 \%$ agreed that teachers were skilled in evaluating individual student's learning and adapting activities according to student needs. In addition, $2.77 \%$ respondents were undecided, $51.66 \%$ subjects disagreed and $23.61 \%$ strongly disagreed with the statement. Henceforth, around $75.27 \%$ disagreement indicated that teachers were not skilled in evaluation of individual student's learning and in adapting activities according to student needs.

With reference to statement 6 , regarding the level of administrative support, $2.77 \%$ of the respondents strongly agreed and $26.94 \%$ agreed that teachers were acquiring administrative support and leadership. However, $6.94 \%$ of respondents' were undecided, $50.85 \%$ respondents disagreed and $12.5 \%$ subjects strongly disagreed with the statement. Thus, approximately $63.35 \%$ of the respondents indicated that teachers were not acquiring administrative support and leadership.

In relation to statement 7 , regarding the language of instruction, $30 \%$ of the respondents strongly agreed and $52.22 \%$ agreed that the language school used for instruction could have positive impact. This impact is on learning and academic achievement in general. On the other hand, $5.29 \%$ respondents were undecided, 11.38 $\%$ respondents disagreed and $1.11 \%$ strongly disagreed with the statement. The greater number of agreements (82.22 \%) indicated that, the language the school uses for instruction had appositive impact on learning and academic achievement in general.

On item 8, related to the level that teachers collaborate, $2.5 \%$ of the respondents strongly agreed and $16.11 \%$ agreed that teachers of different subjects and classes interact in constructive ways to enrich the curriculum. In contrast, $5.57 \%$ respondents were undecided, $26.38 \%$ disagreed and $49.44 \%$ strongly disagreed with the statement. The majority (75.82 \%) indicated that teachers of different subjects and classes did not interact in constructive ways to enrich the curriculum.

Regarding statement 9, that relates to a previous question, $32.77 \%$ respondents strongly agreed and $58.88 \%$ agreed that teachers were being provided opportunities for professional mobility and growth. About $1.11 \%$ was undecided, $3.05 \%$ of the respondents disagreed and $4.19 \%$ strongly disagreed with the statement. A significant majority $(91.65 \%)$ agreed that teachers were provided opportunities for professional mobility and growth.

Concerningstatement10, $6.38 \quad \%$ respondents strongly agreed and $29.47 \%$ agreed that teachers work was prescribing and there was flexibility available to them to perform their professional duties. On the other hand, $3.05 \%$, respondents were undecided, $44.72 \%$ respondents disagreed and $16.38 \%$ strongly disagreed with the statement. The result indicated that the majority (61\%) rejected the idea that teachers' work did not flexibility available to them to perform their professional duties.

As regards statement 11 , the relation of the working conditions to teachers' lives, $1.66 \%$ of the teachers strongly agreed and $3.33 \%$ agreed with the statement. On the other hand, $12.5 \%$ were undecided, $33.33 \%$ of the respondents disagreed and $49.18 \%$ strongly disagreed with the statement. The majority $(82.51 \%)$ contested that teachers working conditions were not compatible with their lives and other responsibilities. 
Table 6. Teachers Perceptions towards Quality Outcomes

\begin{tabular}{|l|l|l|l|l|l|l|}
\hline No & Quality outcome statements & SA (\%) & A (\%) & UD (\%) & DA (\%) & SDA (\%) \\
\hline 1 & $\begin{array}{l}\text { Academic achievement in general and } \\
\text { achievement in literacy and numeracy } \\
\text { in particular represent key educational } \\
\text { outcomes. }\end{array}$ & 34.16 & 53.33 & 2.79 & 6.11 & 3.61 \\
\hline 2 & $\begin{array}{l}\text { The school Using formative assessment } \\
\text { to improve achievement outcomes. }\end{array}$ & 28.36 & 58.88 & 4.16 & 6.66 & 1.94 \\
\hline 3 & $\begin{array}{l}\text { Parents tend to see academic } \\
\text { achievement as closely related to the } \\
\text { opportunity for social promotion and } \\
\text { employment. }\end{array}$ & 2.28 & 28.61 & 6.61 & 50 & 12.5 \\
\hline 4 & $\begin{array}{l}\text { Curricular contents increase students' } \\
\text { knowledge and affect their behavior } \\
\text { related to health and hygiene. }\end{array}$ & 11.15 & 68 & 7.77 & 8.36 & 4.72 \\
\hline
\end{tabular}

Source: Empirical research.

On the subject of item 1, $34.16 \%$ respondents strongly agreed and $53.33 \%$ agreed that academic achievement in general, and achievement in literacy and numeracy in particular, represent key educational outcomes. In contrast, $2.79 \%$ were undecided, $6.11 \%$ of the respondents disagreed and $3.61 \%$ respondents strongly disagreed with the statement. Therefore, most respondents (87.4\%) asserted that academic achievement in general, and achievement in literacy and numeracy in particular, represent key educational outcomes of the school.

Regarding statement $2, \quad 28.36 \%$ respondents strongly agree and $58.88 \%$ agree that the school used formative assessments to improve achievement outcomes. On the other hand, $4.16 \%$ of the respondents were undecided, $6.66 \%$ of the respondents disagreed and $1.94 \%$ strongly disagreed with the statement. The majority (87.24 \%) agreed that schools used formative assessments to improve achievement outcomes.

With reference to statement 3, $2.28 \%$ teachers strongly agreed and $28.61 \%$ agreed with the statement. However, $6.61 \%$ were undecided, $50 \%$ of the respondents disagreed and $12.5 \%$ subjects strongly disagreed with the statements. Based on the results, it appears that the majority (62.5\%) suggested that parents did not tend to see academic achievement as closely related to the opportunity for social promotion and employment.

In relation to item 4, $11.15 \%$ respondents strongly agreed and $68 \%$ agreed that curricular contents increase students' knowledge and had an effect on their behavior, especially related to health and hygiene. On the other hand, $7.77 \%$ were undecided, $8.36 \%$ of the respondents disagreed and $4.72 \%$ of the respondents strongly disagreed with the statement. A majority of the respondents $(79.15$ $\%)$ believed that curricular contents increased students' knowledge and had an effect on their behavior, especially related to health and hygiene.

\section{SUMMARY}

Quality education in these schools studied was influenced by many factors related to the quality of the learner, learning environments, content, processes and quality outcomes. Regarding the quality of the learner, teachers asserted that learners are healthy, well encouraged and ready to participate and learn. On the other hand, several respondents $(32.77 \%)$ believed that learners were not healthy, well nourished, and not ready to participate and learn, and were not supported in learning by their families and communities. The respondents (63.25\%) also indicated that students were not attending classes' consistently. Correspondingly, due to poverty and cultural practices, many parents preferred that children work on family farms rather than going to school, as the employment prospects of education were grim. In contrast, teachers indicated that early experiences and interactions were vital and available in the majority of the elementary school systems.

On the subject of learning environment, the respondents $(77,51 \%)$ indicated that schools provided an adequate number of teachers to deliver quality education. Working conditions for 
students and teachers in the schools (73.62\%) were secure and there were rules and regulations. On the other hand, the availability of instructional materials, textbooks, learning materials, and furniture accessible for learning were influencing children's learning. Likewise, a majority (61.14\%) indicated that there in their school there was a lack of playground and play materials for children. The majority $(81.38 \%)$ did indicate that their school had access to toilets for teachers and students. Conversely, a large number of respondents (66.41\%) cited a lack of clean water supply, which discouraged attendance amongst both boys and girls. Due to this, students went away from the schools and walked distances searching for drinking water; and did not return to class.

Teachers indicated that the class sizes in many schools $(75.85 \%)$ were suitable for teaching and learning. On the contrary, schools size and organization of classrooms influence the instructional method of teachers, for example, arranging seating in a circle to enable maximum interaction instead of lecturing children sitting in rows. The majority school (65.83\%) boarding atmospheres were welcoming and assure students to have warmer and relaxing environment. However, $34.17 \%$ schools' boarding atmospheres were not promise students to have comforting environment. Similarly, different violation conditions were appearing in various school (69.52\%) systems. In examining the support for students with disabilities, many respondents (81.95\%) indicated that the schools did not provide facilities for children with physically disabilities.

On the topic of quality content, a large number of responders (96.64\%) believed that the ability to read, write and calculate were the main goals of a school system. When reflecting on the curriculum, over half of the respondents $(59.18 \%)$ indicated that the curriculum did not depend on local values. Almost the same percentage of respondents $(53.88 \%)$ indicated that student centered, nondiscriminatory, standards based curriculum was the structure employed in the schools. Quite the reverse, the minority respondents (40\%) disagreed that the student centered, nondiscriminatory, standards based curriculum was not used in the schools. When responding to the availability of materials, over half of the respondents $(57.77 \%)$ indicated that the materials were comprehensive, gender sensitive, and relevant to schooling. However, (42.23\%) respondents pointed out that materials were not comprehensive, gender sensitive, and relevant to schooling. Moreover, the majority (61.96 $\%$ ) indicated that the life skill curriculum focused on attitudes, values, and behavioral changes. Thus far, other respondents (938.04 $\%)$ assured that life skill curriculum did not focus on attitudes, values, and behavioral changes.

Concerning the quality process, many respondents (73.9\%) believe that schools had the highest quality teachers, those most capable of helping their students learn, have deep mastery of both their subject matter and pedagogy. However, teachers (52\%) were using traditional methods of instruction. In addition, the findings indicate that ongoing trainings for teachers were not being delivered and teachers did not have opportunities for professional development. Of importance is that the majority of respondents (75\%) indicated that teachers were inefficient in evaluation of individual student's learning and unable to adapt activities according to learners need. Nonetheless, teaching practices (80.77\%) were learner centered and relevant to student's lives. The respondents $(82.22 \%)$ indicated that the language schools used for instruction had a positive impact on learning and academic achievement in general.

Teachers (91.65 \%) were provided opportunities for professional mobility and growth. On the other hand, teachers (62\%) indicated that their schools lacked administrative support and leadership. Seemingly, teachers of different subjects and classes (75.82 \%) were not interacting in constructive ways to enrich the curriculum. Teachers indicated that their work tasks varied (61 \%) and there was not flexibility that allowed them to perform their professional duties. In addition, teachers indicated ( $82.51 \%)$ that working conditions (82.51\%) were not suitable to their life.

\section{CONCLUSION}

Regarding quality learners, in majority of elementary school systems of the region, positive early experiences and interactions were vital. However, students were not attending classes consistently and life skill curriculums were not focus on attitude, values, and behavioral 
changes. Concerning learning environment, research indicated that there were disciplined schools in Amhara region. Schools also provided an adequate number of teachers to deliver quality education. They have access to toilets; the class sizes were suitable for teaching learning. Schools and boarding atmospheres were welcoming and provide students' convenient and relaxing environment. On the other hand, there were scarcity of instructional materials, textbooks, and poor working conditions for students and teachers in schools. Majority schools were not equipped with clean water supply, facilities for children with physically disabilities and playground and play material facilities outside for children to play. The research further declared that political, ethnic and other violation conditions appeared in the school system.

In line with quality content, the finding indicated that the ability to read, write and calculate were the main goals of education. However, the specific content of school curriculum did not depend on local events. Schools have some problems at the level of student centered, nondiscriminatory, standard based curriculum structures employed in the school, in contrast to the impact of local events. Materials in terms of comprehensive, gender sensitive and relevant to schooling was in question.

Towards quality processes, school had highest quality teachers, those most capable of helping their students learn, and who have deep mastery of both their subject matter and pedagogy. Teaching practices were learner centered and relevant to student's lives. The language the school uses for instruction had appositive impact on learning and academic achievement in general. Teachers were provided opportunities for professional mobility and growth. However, teachers were used traditional methods of instruction. The study further proved that ongoing trainings for teachers were not provided for their professional development. Henceforth, they were not skilled in evaluation of individual student's learning and in adapting activities according to student needs. Furthermore, teachers were not acquiring administrative support and leadership. Teachers' work did not flexibility available to them to perform their professional duties. Teachers working conditions were not compatible with their lives and other responsibilities. Because of this, teachers of different subjects and classes did not interact in constructive ways to enrich the curriculum.

Regarding quality outcomes, the study asserted that academic achievement represents key educational outcomes of the school. The finding showed that curricular contents increased students' knowledge and had an effect on their behavior, especially related to health and hygiene. However, the majority parents did not tend to see academic achievement as closely related to the opportunity for social promotion and employment.

\section{RECOMMENDATIONS}

Quality education indicators like school facilities, class size, teachers' behavior and attitude, effective school discipline policies, clean water supply, extra-curricular activities, textbooks, family support, play ground and play materials, facilities for children physically disabilities, school bordering atmospheres, administrative support, violation conditions, and professional flexibilities should be considerably improved and encouraging to enhance the proper teaching process. Quality indicators that address the infrastructure, teacher's behaviors and attitudes, and parental support indicate a need for improvement and provide support for the learning environment. For example, the infrastructure should examine and support effective class sizes, effective school discipline policies, and administrative support. There is a need for a clean water supply, playground and play materials, and facilities for students with physical disabilities. Teachers need professional flexibility and a lack of violation conditions to enhance the teaching process.

More attention should focus on the factors that contribute to a quality education, and how teachers and administrators use information to frame meaningful learning experiences for students. There is a need for ongoing professional development that supports the continuous professional learning of teachers, improves teachers' competence and school efficiency. Ongoing professional development and continuous support could enhance studentcentered learning. At the same time, teachers' working conditions, and supervision and support services should be improved. The findings from the survey and discussion groups can contribute to identifying the components of schooling that improve students' achievement in literacy and 
numeracy, life skills, and health outcomes. These outcomes sought by parents and community members; are required to bring about quality of education in primary schools of Amhara region. Based on these findings, further research related to quality education is indicated to more closely examine the factors needed to improve the educational outcomes of children.

\section{REFERENCES}

BENNETT, J. The relationship between classroom climate and student achievement. 2001. 121f. Dissertation (Doctorate of Education), University of North Texas, 2001.

BERGMANN, H. Quality of education and the demand for education: evidence from developing countries. International Review of Education, v. 42, n. 6, p. 581-604, 1996. Available in: https://link.springer.com/article/10.1007/BF006. Access in: 15 jan. 2020. https://doi.org/10.1007/BF00601404

CARRON, G; CHAU, T. N. The quality of primary schools in different development contexts. Paris: UNESCO, 1996.

CLASON, D. L.; DORMODY, T. J. Analysing data measured by individual Likert-type items. Journal of Agricultural Education, v. 35, n. 4, p. 31-35, 1994. Avaliable in: http://citeseerx.ist.psu.edu/viewdoc/download? doi=10.1.1.113.2197\&rep=rep1\&type=pdf.

Access in: 03 dez. 2018. https://doi.org/10.5032/iae.1994.04031

COLBY, J. Learning outcomes in international context. Paper presented at the Annual Meeting of the Comparative and International Education Society, San Antonio, Texas, 2000.

CRAIG, H.; KRAFT, R.; DU PLISSES, J. Teacher development: making an impact. Washington, D.C.: Academy for Educational Development, ABEL Clearinghouse for Basic Education, 1998.

DESIMONE, L. Linking parent involvement with student achievement: do race and income matter?. The Journal of Educational Research, v. 93, n. 1, p. 11-30, 1999. Avaliable in: https://www.jstor.org/stable/27542243?seq=1.

Access in: 22 jan. 2020.

https://doi.org/10.1080/00220679909597625
ETHIOPIA EARLY GRADE READING ASSESSMENT

DATA ANALYTIC REPORT: Language and Early Learning. 2010. Avaliable in: https://learningportal.iiep.unesco.org/en/library/ ethiopia-early-grade-reading-assessment-dataanalytic-report-language-and-early-learning.

Access in: 07 jun. 2015.

EUROPEAN REPORT. Quality of school education: Sixteen quality indicators, 2000. Avaliable in: http://ec.europa.eu/education/ policies/ educ/ indic/ rapinen.pdf. Access in: 07 jun. 2015.

FEDERAL DEMOCRATIC REPUBLIC GOVERNMENT OF ETHIOPIA. Education training and policy. $1994 . \quad$ Avaliable in: https://planipolis.iiep.unesco.org/sites/planipolis /files/ressources/ethiopia education and trainin g policy.pdf. Access in: 07 jun. 2015.

GLATTHORN, A.; JAILALL, J. Curriculum for the new millennium. In: BRANDT, R. (Ed.), Education in a new era. Alexandria, VA: ASCD, 2000. p. 97121.

HECK, R. H. Examining the impact of school quality on school outcomes and improvement: a value added approach. Educational Administration Quarterly, v. 36, n. 4, p. 513-552, $2000 . \quad$ Avaliable in: https://journals.sagepub.com/doi/10.1177/0013 1610021969092. Access in: 07 jun. 2015. https://doi.org/10.1177/00131610021969092

HENDERSON, A. A new generation of evidence: the family is crucial to student achievement. National Committee for Citizens in Education, Washington, DC, 1994.

KEY EDUCATIONAL SERVICES PLC. Midterm evaluation on improving the quality of basic education in Amhara region. Save the children Norway- Ethiopia: Addis Ababa, 2012.

LATHER, P. Scientific research in education: A critical perspective. British Educational Research Journal, v. 30, n. 6, p. 759-772. 2004. Avaliable in: https://cpb-usw2.wpmucdn.com/u.osu.edu/dist/f/4638/files/2 008/09/lather britj 04.pdf. Access in: 07 jun. 2015.https://doi.org/10.1080/014119204200027 $\underline{9486}$

MAXWELL, J. A. Causal explanation, qualitative 
research, and scientific inquiry in education. Educational Researcher, v. 33, n. 2, p. 3-11. 2004. Avaliable in: https://journals.sagepub.com/doi/10.3102/0013 189X033002003. Access in: 07 jul. 2016. https://doi.org/10.3102/0013189X033002003

MAYER, D. P.; MULLENS, J. E.; MOORE, M. T. Monitoring school quality: an indicators report. Mathematical policy research. Washington, DC: U.S. Department of Education, 2000.

MINISTRY OF FINANCE AND ECONOMIC DEVELOPMENT. Growth and Transformation Plan. Addis Ababa: Ethiopia, 2010.

MOE. Curriculum framework for general education. Addis Ababa, Ethiopia: Ministry of Education, 2010a.

MOE . Education Sector Development Program IV. Addis Ababa, Ethiopia: Ministry of Education, 2010b.

SCHEERENS, J. Conceptual models and theoryembedded principles on effective schooling. School Effectiveness and School Improvement, v. 8, p. 269-310, 1997. Avaliable in: https://www.tandfonline.com/doi/abs/10.1080/0 924345970080301. Access: 07 jul. 2016. https://doi.org/10.1080/0924345970080301

UNICEF . Early childhood care for survival, growth, and development (programming for young children $0-8$ ). Draft summary paper: New York, 1998.

UNICEF. Curriculum report card. Working Paper Series, Education Section, Programmed Division. New York, 2000.

UNICEF. Defining Quality in Education. Working Paper Series, Education Section, Programmed Division: UNICEF, 2000. 